\title{
8. NEW HEAT FLOW VALUES OFF THE WEST COAST OF MOROCCO1
}

\author{
Heinrich Villinger, Institut für Angewandte Geophysik, Petrologie und Lagerstättenforschung Technische \\ Universität Berlin²
}

\begin{abstract}
During Meteor cruise 53 in February 1980, ten heat flow measurements were obtained off the west coast of Morocco. The mean heat flow of all values was $69.4 \pm 18 \mathrm{~mW} / \mathrm{m}^{2}$. This value is slightly higher than values reported by other authors. Abnormally high thermal conductivities were measured in situ and confirmed in the laboratory. The mean heat flow suggests the depth range of the "liquid window," approximately 1300 to $1600 \mathrm{~m}$ below sea bottom.
\end{abstract}

\section{INTRODUCTION}

Recently, the geological and tectonic structure of the west coast of Morocco has been studied in great detail (Wissmann and von Rad, 1979). The Mazagan Escarpment, part of the west coast, provides an interesting site for the investigation of the development of the eastern passive margin of the Atlantic Ocean. Scientists already working in this region proposed the drilling of several boreholes as part of the international Deep Sea Drilling Project. To fulfill the safety regulations of the JOIDES Safety Panel, a detailed geophysical study was made in the vicinity of the Leg 79 holes during cruise 53 of Meteor beginning February 1980. During the geophysical study, heat flow measurements were made in close cooperation with the Niedersächsisches Landesamt Hannover. The objective of the heat flow measurements was to estimate the depth range of the "liquid window" (Pusey, 1973) in this region. The depth range can provide supplementary information concerning the probability of oil or gas deposits, thus reducing the safety risks of drilling. Other heat flow studies (Jessop et al., 1976; Hänel, 1977) have shown that along the west coast of Morocco, only two heat flow measurements were previously available (Nason and Lee, 1964).

The geological, tectonic, and geophysical data which are available for the west coast of Morocco can be found elsewhere in this volume. A list and description of all geophysical measurements made during February 1980 is contained in the cruise 53 report.

\section{GEOTHERMAL STATIONS}

The area of geothermal investigations along the Moroccan continental margin extended from approximately the latitude of Casablanca to Agadir. The stations were concentrated in two regions (Fig. 1), the Mazagan Plateau and the Agadir Canyon. Station positions were determined by satellite with the aid of the INDAS navigation system and errors in latitude and longitude were

\footnotetext{
${ }^{1}$ Hinz, K., Winterer, E. L., et al., Init. Repts. DSDP, 79: Washington (U.S. Govt. Printing Office).

2 Address (present): Pacific Geoscience Centre, 9860 West Saanich Road, P. O. Box 6000 , Sidney, B. C., V8L 4B2, Canada.
}

less than $1000 \mathrm{~m}$. Four stations were situated north and northwest of the Mazagan Plateau in depths of 4000$4300 \mathrm{~m}$. Another group of geothermal measurements was taken along a profile, running from northwest to southeast at a depth of $1500-3000 \mathrm{~m}$. One station was in the region of the Canary Islands, north of Lanzarote.

All geothermal stations were established on profiles where reflection seismics had been made during cruise 53 of Meteor, including the Agadir Canyon. The thickness of the sediment cover obtained from the seismic data was sufficient for heat flow measurements. The age of the ocean bottom around the geothermal stations was estimated at 150 m.y. (Wissmann and von Rad, 1979).

\section{MEASUREMENTS OF HEAT FLOW}

The geothermal measurements were carried out with a modified Ewing-type deep sea probe, developed by Hänel (1972). Two identical probes were used to maximize the time for measurement. Five outriggers, equally spaced at a distance of $1.05 \mathrm{~m}$ and fixed on a piston core barrel, measured the temperature of the sediment as well as the in situ conductivity. Thus the temperature gradient was calculated for a depth interval of $4.20 \mathrm{~m}$ using five temperature values. The accuracy of the temperature measurement was $\pm 0.01^{\circ} \mathrm{C}$. The thermal conductivity was determined in situ according to the needleprobe method (von Herzen and Maxwell, 1959). The outriggers were calibrated in paraffin with a thermal conductivity of $0.26 \mathrm{~W} / \mathrm{mK}$ and the accuracy was about $5 \%$. A pressure vessel contained the electronic equipment used for the control and recording of the measurements. Detailed thermal conductivity measurements were made both aboard and in the laboratory on the recovered sediment cores. The results of these measurements will be discussed below. In general, the cores were shorter than the penetration of the piston core barrel, more than $4.20 \mathrm{~m}$ in most cases.

Figure 2 shows the temperature and in situ thermal conductivity values as a function of depth. The depth is measured from the uppermost sensor, which is designated zero. In those cases where the deep sea probe did not penetrate to the uppermost outrigger, the water-sediment interface is indicated with a horizontal bar (cf. M53-91). The temperature gradient was calculated with 




Figure 1. Heat flow stations and bathymetric chart of the research area. Stations ZEP-26 and ZEP-27 are from Nason and Lee (1964).

the aid of a least-squares fit of the data for each depth interval and is shown in Figure 2. The question of whether the temperature at the water-sediment interface is constant over time is difficult to answer as no thermal measurements at the deep sea bottom in this area have been taken over a period longer than three weeks (Meinke et al., 1975). This time interval is too short to show lowfrequency temperature changes that could seriously disturb the temperature field at a depth greater than $1 \mathrm{~m}$. As the thermal measurements appeared undisturbed by temperature changes at the water-sediment interface, the assumption that the bottom-water temperature is constant can be made. In some cases (cf. M53-91), the temperature of the lowermost sensor is significantly high. This is an effect of friction heating due to the penetration of the probe into the sediment. Extrapolation to equilibrium temperature (Bullard, 1954) gives unrealistic values, hence these measurements were omitted from the calculation of the temperature gradient.

The in situ values for thermal conductivity are shown in Figure 2. The dashed line represents the average thermal conductivity and this value was used to calculate the heat flow. It is remarkable that the thermal conductivity values are so high, $1.3 \mathrm{~W} / \mathrm{mK}$, compared with "nor- mal" values, 0.8-1.0 W/mk (Jessop et al., 1976; Hänel, 1979). Similarily, high values were reported by Kasameyer et al. (1972) for the northwest Atlantic in sediments with high quartz content. Thermal conductivity values were obtained from every recovered core. The measurements were carried out on board the Meteor and in the laboratory with a needle-probe. The in situ values were about $10 \%$ higher than the values measured in the laboratory, possibly due to instrumentation problems. However, there is a good correlation between in situ and laboratory measurements as shown in Figure 3. Table 1 shows a comparison of all in situ and laboratory values. All laboratory values were corrected for temperature and pressure after Ratcliffe (1960). Because the sediment in the cores can be considerably disturbed by the coring technique (Hänel, 1979) and as most of the laboratory measurements were made six months after the cruise, the in situ thermal conductivity values are thus more reliable than the laboratory measurements. But even with an uncertainty of approximately $10 \%$, the thermal conductivities are relatively high.

As the Mazagan Plateau rises very sharply from the ocean basin, topographic corrections were calculated for stations M53-86 and M53-88 after Lachenbruch (1968). 

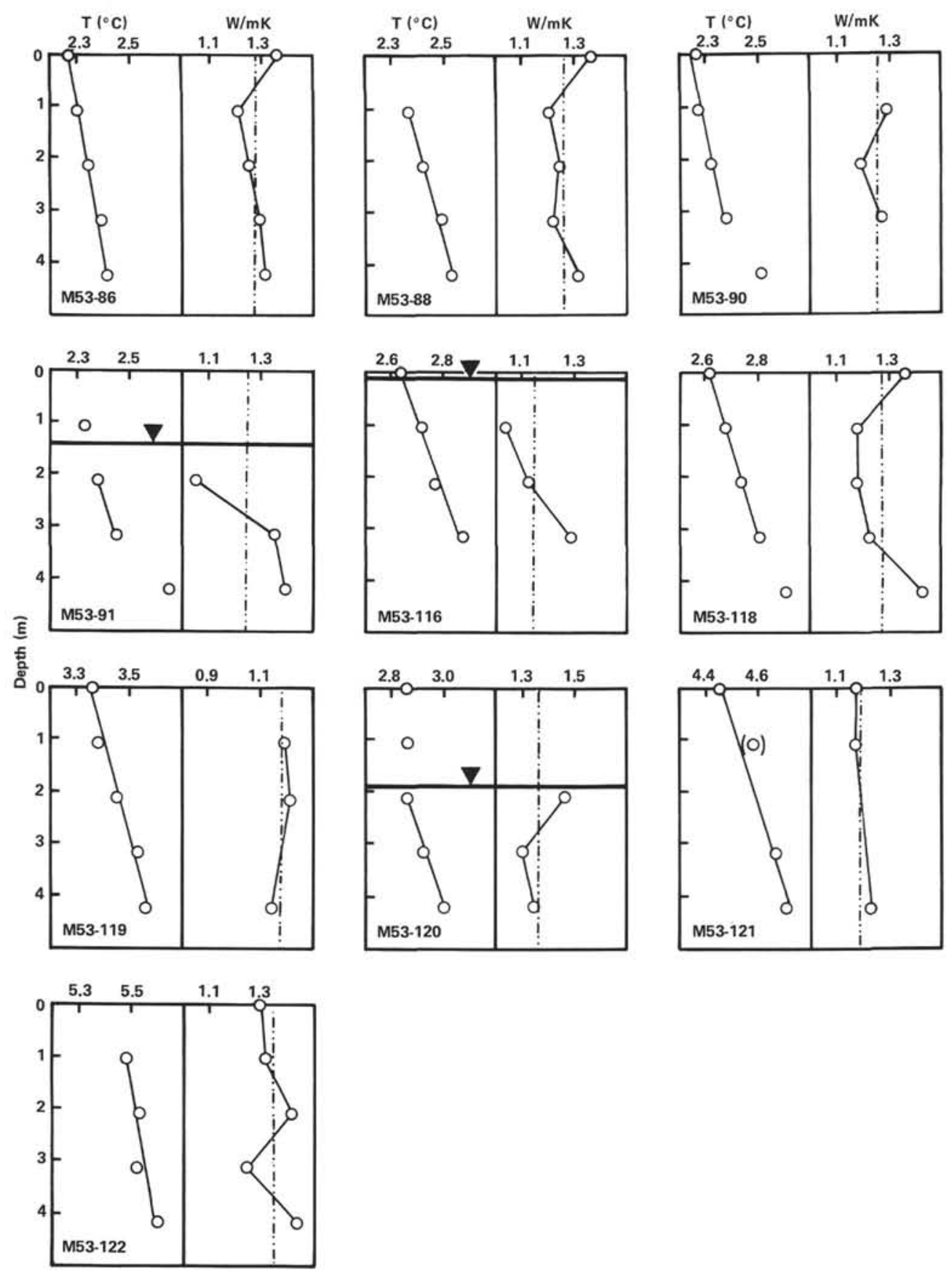

Figure 2. Temperature (left) and in situ thermal conductivity (right) data as a function of depth from all heat flow stations. The depth is measured from the uppermost temperature sensor; the dashed line represents the mean value of the in situ conductivities of the sediment.

These two stations were chosen because they are very close to the rise and their topographic correction allows an estimate of an upper limit. Table 2 shows the topographic corrections. The temperature gradient disturbance due to topographic effects is less than $1 \%$ for the other stations. The sedimentation rate in the investigated area is so low (Wissmann and von Rad, 1979) that it does not need special consideration.

\section{DISCUSSION}

The results from all stations are listed in Table 3. The mean of all measured heat flow values is $69.4 \pm 18$
$\mathrm{mW} / \mathrm{m}^{2}$. According to Herman et al. (1977), the heat flow values in the region of the Canary Islands and to the north are slightly higher than the values in the nonrift areas in the northern Atlantic, the mean being 54.8 $\pm 23.9 \mathrm{~mW} / \mathrm{m}^{2}$. Hänel (1979) gives a similar value, $52.2 \pm 22.4 \mathrm{~mW} / \mathrm{m}^{3}$, for areas of the northeastern part of the Atlantic that lie outside of the immediate vicinity of the ridge axis. Our value is therefore consistent with the upper limit of all previously published value.

A direct comparison of our measurements with those by Nason and Lee (1964) is only possible with certain restrictions. The authors used a modified Bullard probe 


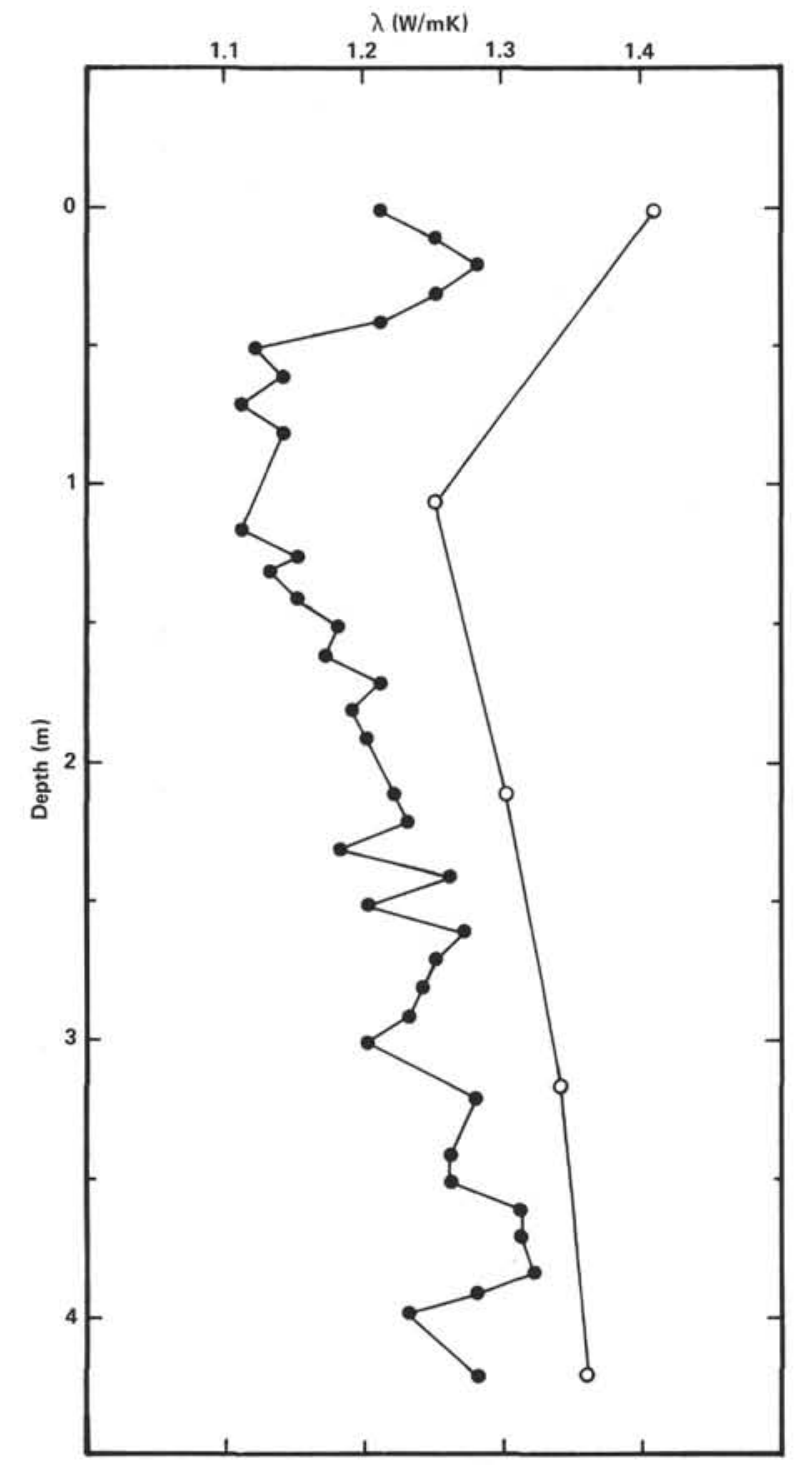

Figure 3. Comparison of in situ thermal conductivity and laboratory values as a function of depth of station M53-88.

Table 1. Comparison of in situ and laboratory values of thermal conductivity.

\begin{tabular}{|c|c|c|c|c|c|}
\hline Station & $\begin{array}{l}\text { Length of } \\
\text { core } \\
\text { (m) }\end{array}$ & $\begin{array}{l}\text { No. of mea- } \\
\text { surements }\end{array}$ & $\begin{array}{c}\lambda \text { laboratory } \\
(\mathrm{W} / \mathrm{mK})\end{array}$ & $\begin{array}{l}\lambda \text { in situ } \\
(\mathrm{W} / \mathrm{mK})\end{array}$ & $\begin{array}{c}\lambda \text { in situ/ } \\
\lambda \text { laboratory }\end{array}$ \\
\hline M53-86 & 420 & 38 & $1.21 \pm 0.07$ & $1.33 \pm 0.05$ & 1.10 \\
\hline M53-88 & 3.40 & 32 & $1.16 \pm 0.07$ & $1.29 \pm 0.07$ & 1.10 \\
\hline M53-90 & 3.18 & 30 & $1.21 \pm 0.08$ & $1.29 \pm 0.05$ & 1.07 \\
\hline M53-91 & 0.72 & 6 & $1.20 \pm 0.04$ & $1.30 \pm 0.19$ & 1.08 \\
\hline M53-116 & 1.67 & 17 & $1.11 \pm 0.05$ & $1.18 \pm 0.12$ & 1.06 \\
\hline M53-118 & 2.50 & 23 & $1.15 \pm 0.08$ & $1.32 \pm 0.11$ & 1.15 \\
\hline M53-119 & 3.70 & 35 & $1.18 \pm 0.04$ & $1.21 \pm 0.04$ & 1.03 \\
\hline M53-120 & 0.90 & 9 & $1.20 \pm 0.06$ & $1.40 \pm 0.08$ & 1.17 \\
\hline M53-121 & 2.70 & 26 & $1.16 \pm 0.04$ & $1.22 \pm 0.03$ & 1.05 \\
\hline M53-122 & 2.30 & 14 & $1.15 \pm 0.03$ & $1.38 \pm 0.08$ & 1.20 \\
\hline
\end{tabular}

Note: Mean of all laboratory measurements $1.17 \pm 0.03 \mathrm{~W} / \mathrm{mK}$; mean of all in situ measurements $1.29 \pm 0.07 \mathrm{~W} / \mathrm{mK}$.

and calculated the gradient using only two measurements $2 \mathrm{~m}$ apart. The penetration depth of the lowermost sensor was about $2 \mathrm{~m}$. Calculating the temperature gradient with only two values can lead to serious errors
Table 2. Topographic corrections for Station M53-86 and M53-88 (after Lachenbruch, 1968).

\begin{tabular}{cccc}
\hline Station & Position & $\begin{array}{c}\text { Disturbed } \\
\text { gradient } \\
\left({ }^{\circ} \mathrm{C} / \mathrm{m}\right)\end{array}$ & $\begin{array}{c}\text { Corrected } \\
\text { gradient } \\
\left({ }^{\circ} \mathrm{C} / \mathrm{m}\right)\end{array}$ \\
\hline M53-86 & $\begin{array}{r}33^{\circ} 50.9^{\prime} \mathrm{N} \\
9^{\circ} 16.9^{\prime} \mathrm{W}\end{array}$ & 0.0352 & 0.0329 \\
M53-88 & $\begin{array}{r}33^{\circ} 54.7^{\prime} \mathrm{N} \\
9^{\circ} 23.3^{\prime} \mathrm{W}\end{array}$ & 0.0524 & 0.0505 \\
& & \\
\hline
\end{tabular}

Table 3. Heat flow values off the west coast of Morocco.

\begin{tabular}{|c|c|c|c|c|c|c|c|}
\hline $\begin{array}{c}\text { Station } \\
\text { no. }\end{array}$ & $\underset{\text { Lat. }}{\text { Lat }}$ & $\begin{array}{l}\text { Long. } \\
\text { w }\end{array}$ & $\begin{array}{l}\text { Depth } \\
\text { (m) }\end{array}$ & $\begin{array}{l}\text { Water } \\
\text { temp. } \\
\left({ }^{\circ} \mathrm{C}\right)\end{array}$ & $\begin{array}{l}\text { Mean thermal } \\
\text { conductivity } \\
(\mathrm{W} / \mathrm{mK})\end{array}$ & $\begin{array}{c}\text { Mean temperature } \\
\text { gradient } \\
\left({ }^{\circ} \mathrm{C} / \mathrm{m}\right)\end{array}$ & $\begin{array}{c}\text { Mean heat } \\
\text { flow } \\
\left(\mathrm{mW} / \mathrm{m}^{2}\right)\end{array}$ \\
\hline M53-86 & $33^{\circ} 50.9^{\prime}$ & $9^{\circ} 16.9^{\prime}$ & 3898 & 2.3 & $1.33 \pm 0.05$ & 0.0329 & 43.8 \\
\hline MS3-88 & $33^{\circ} 54.7^{\prime}$ & $9^{\circ} 23.3^{\prime}$ & 3903 & 2.3 & $1.29 \pm 0.07$ & 0.0505 & 65.1 \\
\hline M53-90 & $33^{\circ} 51.3^{\prime}$ & $10^{\circ} 5.3^{\prime}$ & 4313 & 2.2 & $1.29 \pm 0.05$ & 0.0390 & 50.3 \\
\hline M53-91 & $33^{\circ} 49.5^{\prime}$ & $10^{\circ} 16.4^{\prime}$ & 4325 & 2.3 & $1.30 \pm 0.19$ & 0.0684 & 88.9 \\
\hline M53-116 & $30^{\circ} 8.6^{\prime}$ & $14^{\circ} 2.8^{\prime}$ & 3125 & 2.6 & $1.18 \pm 0.12$ & 0.0733 & 86.5 \\
\hline M53-118 & $31^{\circ} 5.9^{\prime}$ & $11^{\circ} 36,4^{\prime}$ & 3094 & 2.6 & $1.32 \pm 0.11$ & 0.0600 & 79.2 \\
\hline M53-119 & $30^{\circ} 51.5^{\prime}$ & $11^{\circ} 21.7^{\prime}$ & 2400 & 3.3 & $1.21 \pm 0.04$ & 0.0524 & 63.4 \\
\hline M53-120 & $30^{\circ} 43.6^{\prime}$ & $11^{\circ} 14.8^{\prime}$ & 2753 & 2.8 & $1.40 \pm 0.08$ & 0.0667 & 93.4 \\
\hline M53-121 & $30^{\circ} 24.5^{\prime}$ & $10^{\circ} 54.5^{\prime}$ & 1960 & 4.4 & $1.22 \pm 0.03$ & 0.0637 & 77.7 \\
\hline \multirow[t]{2}{*}{ M53-122 } & $30^{\circ} 9.3^{\prime}$ & $10^{\circ} 38.3^{\prime}$ & 1730 & 5.4 & $1.38 \pm 0.08$ & 0.0333 & 45.9 \\
\hline & & & & mean & $1.29 \pm 0.07$ & $0.0540 \pm 0.015$ & $69.4 \pm$ \\
\hline ZEP-26a & $31^{\circ} 12^{\prime}$ & $11^{\circ} 50^{\prime}$ & 3210 & & 0.92 & 0.05 & 45.0 \\
\hline ZEP-27 $7^{a}$ & $33^{\circ} 35^{\prime}$ & $9^{\circ} 43^{\prime}$ & 4340 & & 0.92 & 0.045 & 41.4 \\
\hline
\end{tabular}

Note: ${ }^{a}$ values after Nason and Lee (1964).

unless the accuracy of the temperature measurements is extremely high. The authors themselves consider the values of ZEP-26 to be uncertain. Therefore, a comparison would be limited in its usefulness.

The objective of the heat flow survey was to get an estimated depth of the "liquid window." The concept of the "liquid window" was established by Pusey (1973) who found a direct relationship between temperature distribution underground and hydrocarbon generation and accumulation (Fig. 4) in the presence of a constant temperature gradient. The geothermal gradient is the crucial parameter in the "liquid window" concept. This value is easily determined if temperature is measured as a function of depth as it is in boreholes. However, in the present survey, the measured heat flow values and estimates of the thermal conductivity of the sediments were used to calculate the temperature gradient for a depth up to $1500 \mathrm{~m}$. Using the mean heat flow of $69.4 \pm 18$ $\mathrm{mW} / \mathrm{m}^{2}$ and estimated thermal conductivities for the sediments between 2.0 and $2.5 \mathrm{~W} / \mathrm{mK}$ (Kappelmeyer and Hänel, 1974), the resulting gradients for depth are between 0.035 and $0.028^{\circ} \mathrm{C} / \mathrm{m}$. Thus, for these gradients, the "liquid window" starts at a depth between 1300 and $1600 \mathrm{~m}$ (Pusey, 1973) and could only be reached by the deepest holes planned during DSDP Leg 79. The estimated temperatures could have been checked in the Leg 79 holes in April 1981 but, because of technical problems, no reliable temperature measurements were made.

\section{ACKNOWLEDGMENTS}

This work was kindly supported by the Deutsche Forschungsgemeinschaft. Many thanks go to Captain Feldmann and his crew aboard Meteor. I am very indebted to F. Böker (NLfB, Hannover) who did his very best to keep the deep sea probes in operation. Thanks also to Dr. R. Hänel (NLfB, Hannover) and Prof. Dr. J. Behrens (Technische Universität, Berlin) who gave me the opportunity to make these measurements. Critical comments on the paper from C. Clauser, Dr. 


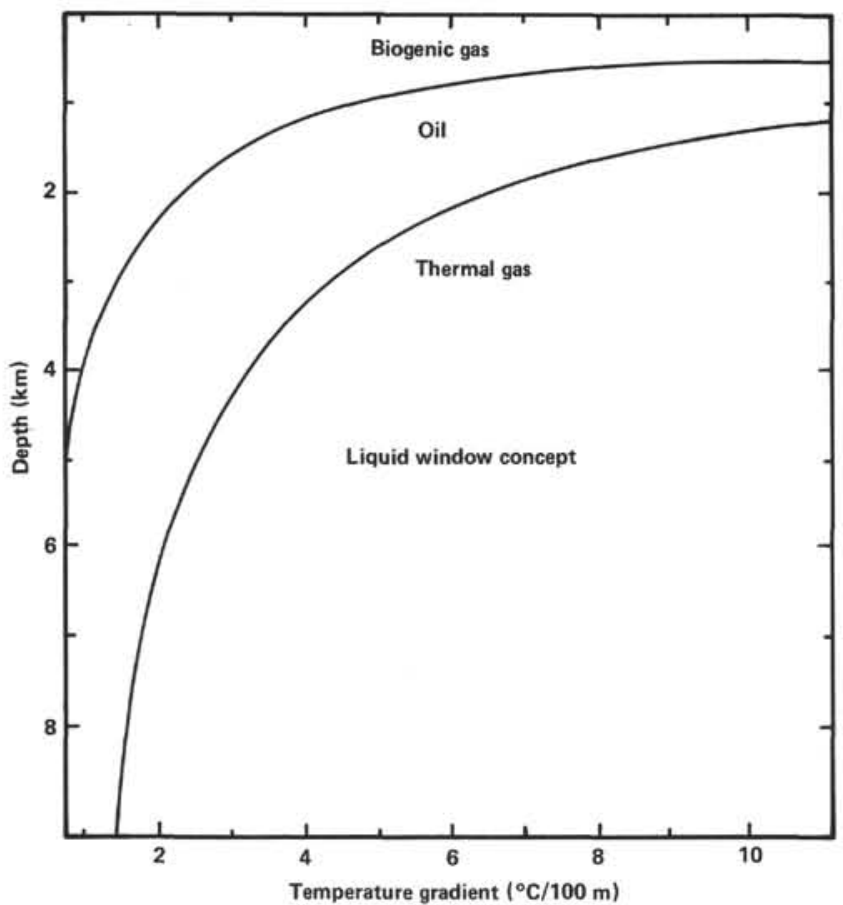

Figure 4. The "liquid window" concept and theoretical oil prospects in sedimentary basins (redrawn after Pusey, 1973).

K. Bram, and Dr. R. Hänel were most helpful. M. Weigold (Technische Universität, Berlin) performed the thermal conductivity measurements in the laboratory. Thanks also to U. Töpper who drew the figures and to my wife, R. Villinger who did the typing (both Technische Universität, Berlin). The critical comments of Dr. R. von Herzen and second reviewer are kindly acknowledged.

\section{REFERENCFS}

Bram, K., 1980. New heat flow determinations on the Reykjanes Ridge. J. Geophys., 47:86-90.
Bullard, E., 1954. The flow of heat through the floor of the Atlantic Ocean. Proc. Roy. Soc. London, A222:408-429.

Hänel, R. 1972. Heat flow measurements in the Ionian Sea with a new heat flow probe. Meteor Forsch.-Ergebnisse, C, 11:105-108.

1979. A critical review of heat flow measurements in sea and lake bottom sediments. In Cermák, V., and Rybach, L. (Eds.), Terrestrial heat flow in Europe: Berlin, (Springer Verlag), pp. 49-73.

Herman, B. M., Langseth, M. G., and Hobart, M. A., 1977. Heat flow in the oceanic crust bounding western Africa. Tectonophysics, 41:61-77.

Jessop, A. M., Hobart, M. A., and Sclater, J. G., 1976. The world heat flow data collection 1975. Geothermal Service of Canada, Ottawa, Geoth. Ser. 5.

Kappelmeyer, O., and Hänel, R., 1974. Geothermics. Berlin (Bornträger Verlag).

Kasameyer, P. W., von Herzen, R., and Simmons, G., 1972. Layers of high thermal conductivity in the North Atlantic. J. Geophys. Res., 77:3162-3167.

Lachenbruch, A. H., 1969. Rapid estimation of the topographic disturbance to superfical thermal gradients. Rev. Geophys., 6: $365-400$.

Meincke, J., Mittelstaedt, E., Huber, K., and Kontermann, K. P., 1975. Stömung und Schichtung im Auftriebsgebiet vor NordwestAfrika. DHI Hamburg, Meereskundliche Beobachtungen und Ergebnisse, 41.

Nason, R. D., and Lee, W. H. K., 1964. Heat flow measurements in the North Atlantic, Carribean and Mediterranean. J. Geophys. Res., 69:4875-4883.

Pusey, W. C., 1973. How to evaluate potential gas and oil source rocks. World Oil, 176:71-75.

Ratcliffe, E. H., 1960. The thermal conductivity of ocean sediments. J. Geophys. Res., 65:1535-1541.

von Herzen, R., and Maxwell, A. E., 1959. The measurements of thermal conductivity of deep sea sediments by a needle-probe method. J. Geophys. Res., 64:1557-1563.

Wissmann, G., and von Rad, K. 1979. Seismic structure, continental basement, and Mesozoic sediments from the Magazan Plateau of Morocco. Meteor Forsch.-Ergebnisse, C, 31:1-20.

Date of Initial Receipt: January 19, 1983

Date of Acceptance: July 11, 1983 